\title{
IMPACT OF IRRIGATION INTERVALS, PLANTING TIME AND DENSITY ON HIBISCUS YIELD
}

\author{
Mansour H. El-Bakhshwan ${ }^{1}$ and Hamed M. El-Kouny ${ }^{2}$
}

\section{ABSTRACT}

Field experiment was carried out at Tractors and Farm Machinery Testing \&Research Station, Alex. Governorate, Egypt, during the summer season of 2017, to study the impact of planting time, plant density and irrigation intervals on the hibiscus yield in terms of plant height, number of branches, number of flowers, flowers weight, seeds weight and flower hay weight. A split-plot experiment was carried out in the field based on a randomized complete block design with three replications. This work was accomplished by designing 54 experimental units. The main plot was planting time ( 1 June $T_{1}$ and 2 July $T_{2}$ ) and the sub-plot was three irrigation intervals [ $\left(I_{1}\right)$ every week, $(4000 \mathrm{~m} 3 / \mathrm{fed})$ according to the Desert Research Center (2010), ( $\left.I_{2}\right)$ every two weeks, (2000 m3/fed) and $\left(I_{3}\right)$ every three weeks (1000 m3/fed $\left.)\right]$ and three plant densities, $\left[D_{1}, 20\right.$ $\mathrm{cm}$ (16000 plants/fed), $D_{2}, 40 \mathrm{~cm}(10000$ plants/fed $)$ and $D_{3}, 60 \mathrm{~cm}$ (6670 plants/fed)).

The results showed that the delay in sowing from June 1 to July 2 decreased fruit number and number of branches per plant significantly, the highest values were 74.2 and 13.2 for the treatment $T_{1} D_{2} I_{3}$, respectively and the lowest values were 34.6 and 4.1 for the treatment $T_{2} D_{1} I_{1}$ respectively. Also, all the values of the crop characteristics such as the flowers weight and the seeds weight were decreased when the planting time was delayed where the highest values were 337.8 and 850 $\mathrm{kg} / \mathrm{fed}$ resulted from the treatment $T_{1} D_{2} I_{3}$, respectively while the lowest values were 254 and $647.5 \mathrm{~kg} / \mathrm{fed}$ resulted from the treatments $T_{2} D_{1} I_{1}$, respectively. The plant height was significantly affected by the planting time. The earlier it was the higher the value, of plant height. The highest value $206.5 \mathrm{~cm}$ for the treatment $T_{1} D_{1} I_{1}$, and the lowest was $121.3 \mathrm{~cm}$ for the treatment $T_{2} D_{3} I_{3}$.

1- Agricultural Engineering Research Institute, Agriculture Research Centre, Egypt.

2- Soil water and environment Research Institute, Agriculture Research Centre, Egypt. 
Generally the early planting time with all irrigation intervals and plant densities showed significant effect on the crop characteristics, where the highest values resulted from the treatment $T_{1} D_{2} I_{3}$, while the lowest values were obtained form the treatment $T_{2} D_{1} I_{1}$, in terms of flowers, the number of branches, the weight of flowers and the weight of seeds, while the highest value for plant height was for the treatment $T_{1} D_{1} I_{1}$ and the lowest value was for the treatment $T_{2} D_{3} I_{3}$. The treatment $T_{1} D_{2} I_{3}$ showed the highest value for the water use efficiency 0.34 , and the lowest value was 0.06 for the treatment $T_{2} D_{1} I_{1}$.

The objectives of this work were to study the possibility of the hibiscus (Roselle) cultivation in the lower part of Egypt and the effect of irrigation level, plant density and sowing date on its yield and some morphophysiological traits.

Key words: Roselle, sowing date, plant density, yield, yield components.

\section{INTRODUCTION}

$\mathrm{H}$ ibiscus (Roselle) is grown to obtain the red caterpillars, or the fibres or double purposes. The fibres are used in the cords residues are for animal feed or fertilization. Roselle (Hibiscus sabdariffa. L) belongs to the Malvaceae family, and is an annual or biennial plant cultivated in tropical and subtropical regions for its stem fibres, edible calyces, leaves and seeds. Cultivation of the crop has been reported throughout the Indian sub- continents, part of Asia, America, Australia, and throughout Africa (Cobley, 1968). (Rao, 1996) reported that the Roselle plant is grown in some regions for fibre and pulp obtained from its stem. Close to $17 \%$ of edible oil is extractable from the seed, which is also used as poultry feed.

Egypt is considered as the country in which Roselle originated (El-Sayed et al. 1998; FAO, 2004; Leung and Foster, 1996; Ismail et al. 2008). However, research on the effect of irrigation mainly water deficit technique on postharvest quality of Roselle and its growth development is still scarce. Proper practices of irrigation management and the cultivation of drought-resistant crops are some effective techniques for improving the utilization of the limited water resources in these regions. Roselle 
(Hibiscus sabdariffa) belongs to the family of Malvaceae and is a drought-adapted crop (El-Boraie $\boldsymbol{e t}$ al., 2009). Water deficit techniques such as regulated deficit irrigation (RDI), withholding irrigation (WHI) and partial rootzone drying (PRD) have been widely implemented in various countries mainly to improve water use efficiency and growth performance of various crops. Hibiscus plants are affected by different irrigation quantities, and the periods of irrigation, where the large quantities of water push the plant to grow vegetative and produce long fiber and vice versa. Babatunde and Mofoke (2006) reported that the influence of irrigation schedule on the yield of roselle measured with respect to fresh calyx weight was highly significant. El- Boraie et al (2009) found that the shortest plants were produced due to the heaviest plant densities and irrigation water schedule (When using water quantity at water level $80 \%$ ), also the number of flowers for hibiscus were increased. The effect of highest irrigation level and early sowing date on plant height, stem diameter and branch number was not significant and Chlorophyll index decreased with the increase in irrigation level (Seghatoleslami et al, 2013). Naimah et al (2013) reported that water deficit treatments showed a significant effect on fresh weight of roselle calyx. The $20 \%$ regulated deficit irrigation RDI $(860 \mathrm{~mL}$ water per plant per day) increased yield and maintained plant growth without adversely affecting calyx quality. The $20 \%$ RDI also saved $20 \%$ irrigation water and increased irrigation use efficienc. Shubhra et al., (2004) found that plant height and the number of flowers per plant were considerably decreased under drought stress conditions. Daneshmand et al. (2008) studied the effect of irrigation treatments on stomatal conductance and leaf chlorophyll content in rape and reported that stomatal conductance and chlorophyll content decreased as the moisture content of the soil was decreased. Choosing an appropriate sowing date for a crop is one of the most important factors in its production when it is cultivated for the first time in a region. Appropriate sowing date of a crop is a date when the plants can well establish and their susceptible growth stages do not coincide with adverse environmental conditions. Roselle planting date Performed to get the best productivity of crops and the optimal economic benefits (Naeve et al., 2004). Barzgaran (2010) founded that 
the delay in sowing for the roselle from May 10 to June 20 lead to the loss of flower number per $\mathrm{m} 2$, flower fresh yield flower dry yield and biological yield. Wrong sowing date brings about the loss of yield by influencing some physiological attributes. The delayed sowing date decreased chlorophyll content of rice (ElKhoby, 2004). In a study on the effect of fives sowing dates (April 19, April 30, May 10, May 20 and May 31) on rice, where the temperature of day and night and intensity of light affected the flower inductions and yield production (Naeve et al. 2004). Late planting date has a direct impact on the crop vegetative growth and reproduction (Board et al. 1992, 1999; Boquet, 1990; Kantolic and Slafer, 2001). Bremner (1996) concluded that the dry weight of sesame plant decreased as the sowing date was delayed. El Sherif, F. and S. Khattab (2012) reported that the early planting of rosella is the suitable time to produce the highest growth and yield. Ado. G. et al (2015) indicated that early planting of Roselle using 1plant/stand resulted in higher number of leaves and more fruits/plant as well as improve In total calyx yield. It is known that the plant vegetative characteristics have a direct relation with agricultural practices such as plant densities, which mostly affected the vegetative growth and then the yield. (Khater and Ahmed 1992) the plant height was increased by decreasing planting distances.

The study at finding out the effect of Seed Density and Planting Date on yield and growth of Roselle Hibiscus safdariffa (Shubhra,et al2004 ) studied the effect of sowing date and plant density on yield and agronomical traits of roselle, it was reported that the delay in sowing significantly decreased sepal weight, also, they found that the highest yield was obtained from planting on one side ridge and $50 \mathrm{~cm}$ spacing between plants.( Shalaby and Rasin 1989) found that the widest spacing produced the greatest number of fruits per plant. High productive potentials has been reported for Roselle grown under rain fed, through various agronomic practices such as weeding and spacing (Babatunde and Zechariah, 2001); intercropping, sowing dates, intrarow spacing and nitrogen fertilizer (Babatunde, 2003).

(Seyyed Gholam and Reza Moosavi 2011) reported that delayed sowing of roselle significantly decreased its economical yield (sepal 
yield) through shortening the vegetative growth period and branching potential and decreasing the fruit number per unit area on the one hand, while it encountered plants with autumn chilling and decreased or stopped fruit and sepal growth on the other hand. In addition, at higher densities, fierce shading decreased.

The objectives of this study were to determine the appropriate Date of planting Roselle for better Performance. - To verify irrigation intervals and the suitable seed density for the improved growth of Roselle,

\section{MATERIAL AND METHODS}

\section{Experimental sites:}

Field experiment was carried out during the summer season of 2017 at Tractors and Farm Machinery Testing and Research Station at Sabahia, Alexandria Governorate, Egypt, to study the effect of irrigation intervals, planting time and density on hibiscus yield, as well as some physicochemical properties of soil.

\section{Soil description:}

Soil samples were collected and analyzed to determine some physical and chemical characteristics of the investigated soil according to the standard methods outlined by Black et. al. (1965), Jackson (1967) and Page et al. (1982). Total nitrogen $(\mathrm{T}-\mathrm{N})$ and available $(\mathrm{Av}-\mathrm{N})$ were extracted and determined according to the methods under taken by Jackson (1973). Data are represented in Table 1.

\section{Chemical analysis of water:}

The chemical analysis of water was carried out and analyzed in Saline and Alkaline Research Lab Alexandria.

\section{Planting treatments and experimental design}

The experiment was performed in split split- plot system in a randomized complete block design (RCBD) with three replicates. The field was divided to 54 plots. The main and sub main treatments were as follows:

The main plot is planting times at ( 1 June $\mathrm{T}_{1}$ and 2 July $\mathrm{T}_{2}$ ) and the subplot had three irrigation intervals [ $\left(\mathrm{I}_{1}\right)$ every week, $\left(4000 \mathrm{~m}^{3} / \mathrm{fed}\right)$ according to the Desert Research Center (2010), $\left(\mathrm{I}_{2}\right)$ every two weeks, $\left(2000 \mathrm{~m}^{3} / \mathrm{fed}\right)$ and $\left(\mathrm{I}_{3}\right)$ every three weeks $\left.\left(1000 \mathrm{~m}^{3} / \mathrm{fed}\right)\right]$ and three plant densities,[D, $25 \mathrm{~cm}$ (16000 plants/fed), $\mathrm{D}_{2}, 40 \mathrm{~cm}$ (10000 plants/fed) 
and $\mathrm{D}_{3}, 60 \mathrm{~cm}(6670$ plants/fed $\left.)\right)(25-40$ and $60 \mathrm{~cm}$ the distance between the plants in the row, respectively)] .

Table (1). Some physical and chemical properties of the tested soil.

\begin{tabular}{|c|c|c|}
\hline & Properties & The values \\
\hline \multicolumn{3}{|c|}{ Chemical properties } \\
\hline \multirow{4}{*}{ Soluble Cations (meq/L) } & $\mathrm{Na}^{1}$ & 4.80 \\
\hline & $\mathrm{K}^{+}$ & 0.10 \\
\hline & $\mathrm{Ca}^{+2}$ & 11.50 \\
\hline & $\mathrm{Mg}^{+2}$ & 5.66 \\
\hline \multirow{3}{*}{ Soluble anions $(\mathrm{meg} / \mathrm{L})$} & $\mathrm{HCO}_{3}$ & 7.00 \\
\hline & $\mathrm{CL}^{+}$ & 5.50 \\
\hline & $\mathrm{SO}^{-2}{ }_{4}$ & 9.66 \\
\hline \multicolumn{2}{|c|}{ Total Carbonat \% $\left(\mathrm{CaCo}_{3}\right)$} & 4.85 \\
\hline \multicolumn{2}{|c|}{ Cation exhangable capacity (CEC) meg/100 soil } & 9.55 \\
\hline \multicolumn{3}{|c|}{ Physical properties } \\
\hline \multicolumn{2}{|l|}{ Total porosity, (T.P) \% } & 51.25 \\
\hline \multicolumn{2}{|c|}{ Hydraulic Conductively $(\mathrm{HC})(\mathrm{cm} / \mathrm{h})$} & 01.75 \\
\hline \multicolumn{2}{|c|}{ Available water, (Av.W) \% } & 17.95 \\
\hline \multirow{4}{*}{ Particle size distribution, $\%$} & Texture class & Sand clay loam \\
\hline & Sand & 44.20 \\
\hline & Loam & 26.10 \\
\hline & Clay & 29.70 \\
\hline
\end{tabular}

Table(2): Irrigation water chemical analysis

\begin{tabular}{|l|l|l|l|l|l|l|l|l|}
\hline $\begin{array}{c}\text { Ecdsm } \\
1\end{array}$ & $\mathrm{P}^{\mathrm{H}}$ & $\mathrm{Ca}^{++}$ & $\mathrm{Mg}^{++}$ & $\mathrm{Na}^{+}$ & $\mathrm{K}^{+}$ & $\mathrm{CO}^{--}$ & $\mathrm{HCO}^{--}$ & $\mathrm{Cl}^{-}$ \\
\hline $\mathbf{1 . 2 0}$ & $\mathbf{7 . 9 5}$ & $\mathbf{0 . 9 0}$ & $\mathbf{0 . 2 5}$ & $\mathbf{0 . 1 5}$ & $\mathbf{8 . 0 0}$ & $\mathbf{0 . 0 0}$ & $\mathbf{0 . 3 0}$ & $\mathbf{0 . 8}$ \\
\hline
\end{tabular}

Hibiscus seeds were sown in the soil in row 10.0 m length and $0.1 \mathrm{~m}$ apart, the spacing. The seeds were soaked in water for 24 hours and then placed as two seeds in each hole (Seeds were sown in holes at space of $(0.25-0.40-0.60 \mathrm{~m})$ in between, Thinning process to one plant per hole was performed 30 days after sowing. The total area of the experiment was about $210 \mathrm{~m}^{2}$, divided into 54 plots; each plot area was $(3.0 \mathrm{~m} \mathrm{x1.0} \mathrm{m)}$. Plants were irrigated by flooding irrigation. The plants were harvested in the first November and its growth parameters data were recorded: plant height, number of main branches per plant, number of umbels per plant, weight of seeds and production of flowers (yield of flowers).

\section{Crops planting:}

The hibiscus seeds were sown at a seed rate of about $7.5 \mathrm{~kg}$ per feddan. 


\section{Data collection:}

The plant growth parameters measured were as follows:

a) Number of branch per plant:

b) Plant height:

c) Weight of seeds

d) Yield of flowers

e) Weight of straw flowers

Five plants were taken at random from each replicate

Water use efficiency (WUE):

Water use efficiency is the measure of a cropping system's capacity to convert water into plant biomass or grains. Water use efficiency (WUE) was determined according to Michael (1978) by using the following equation,

Water use efficiency $=$ Crop yield,$\left(\mathrm{kg} \mathrm{fed}^{-1}\right) /$ Water applied, $\left(\mathrm{m}^{3} \mathrm{fed}^{-1}\right)$

\section{Statistical analysis:}

All data were subjected to the statistical analysis according to Sedecor and Cochran (1980) to define the least significant difference test (L.S.D. at $\mathrm{p}=0.05$ level)

\section{RESULTS AND DISCUSSION}

Effect of irrigation intervals, planting time and density on hibiscus yield The results generally showed high significant effect of the three treatments: (periods of irrigation, plant densities and sowing date) on all the hibiscus crop characteristics in terms of plant height, number of branches, number of flowers, flower weight, and seed weight when it is planted not only for obtaining flowers and seeds, but also for attaining fibers, flowers and seeds together.

Table (3) showed the effect of irrigation intervals, planting time and density on hibiscus yield, No. of branches/plant, No. of fruits, weight of sepals, weight of seeds and weight of flower hay. The illustrated data showed a progressive significant increase of all treatment with $T_{1} D_{2} I_{3}$ compared with other treatments. The greatest mean value of No. of branches/plant was 13.2 with $\left(\mathrm{T}_{1} \mathrm{D}_{2} \mathrm{I}_{3}\right)$ which was planted in 1 June $\left(\mathrm{T}_{1}\right)$ and the distance between the plants $40 \mathrm{~cm}$ (D2) and a period of irrigation once every three weeks and quantity of water $1000 \mathrm{~m}^{3} /$ fed.( $\left(\mathrm{I}_{3}\right)$. 
Table (3): Effect of irrigation intervals, planting time and density on hibiscus yield

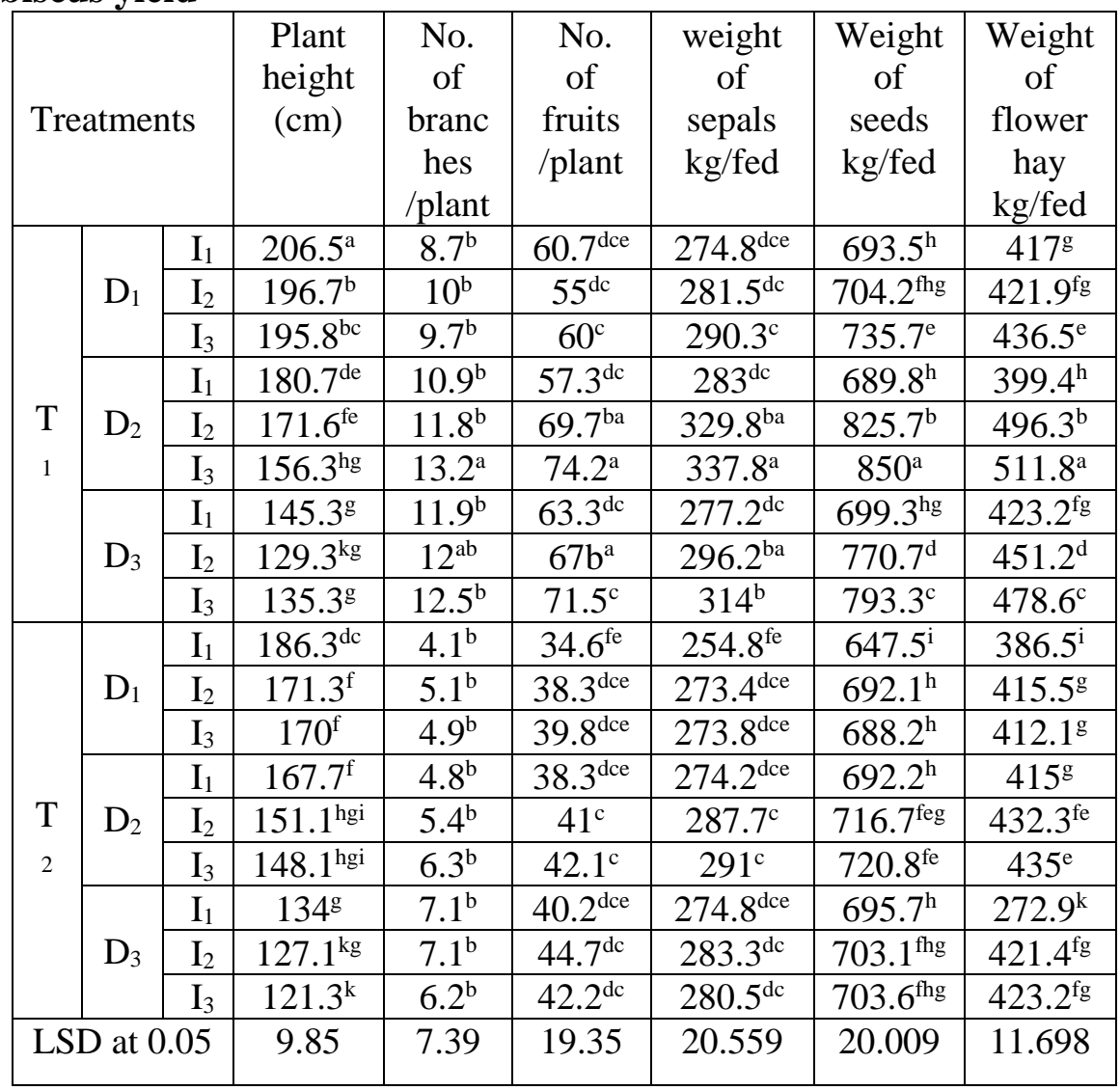

Where:

$\mathrm{T}_{1:}$ first planting time at 1 June

$\mathrm{T}_{2}$ : second planting time at 2 July

$\mathrm{D}_{1}$ : density of plants (16000plant/fed) at $25 \mathrm{~cm}$ between plants

$\mathrm{D}_{2}$ : density of plants (10000plant/fed) at $40 \mathrm{~cm}$ between plants

$\mathrm{D}_{3}$ : density of plants (6670plant/fed) at $60 \mathrm{~cm}$ between plants

$\mathrm{I}_{1}$ : first irrigation intervals every week, $\left(4000 \mathrm{~m}^{3} / \mathrm{fed}\right)$

$\mathrm{I}_{2}$ : second irrigation intervals every two weeks, $\left(2000 \mathrm{~m}^{3} / \mathrm{fed}\right)$

$\mathrm{I}_{3}$ : third irrigation intervals every three weeks $\left.\left(1000 \mathrm{~m}^{3} / \mathrm{fed}\right)\right]$

The greatest mean value for: number of flowers, flower weight, and seed weight $74.2,337.8$, and 850 respectively with $\left(\mathrm{T}_{1} \mathrm{D}_{2} \mathrm{I}_{3}\right)$. The greatest mean value of plant height $(\mathrm{cm})$ was 206.5 resulted from the treatment $\left(\mathrm{T}_{1} \mathrm{D}_{1} \mathrm{I}_{1}\right)$, 
while lowest value was 121.3 for the treatment $\left(\mathrm{T}_{2} \mathrm{D}_{3} \mathrm{I}_{3}\right)$. The positive response of irrigation intervals, planting time and density on hibiscus yield was displayed by many authors such as Shubhra et al.(2004), El Khoby(2004), Board et al. (1992),(1999), Kantolic and Slafer(2001), and Barzgaran T (2010).

\section{Effect of planting dates on the characteristics of hibiscus:}

Table 3 shows that all plant characteristics (plant height, number of branches, number of flowers, flower weight and seed weight) decreased with July planting time compared to June one which agreed with Naeve et al. (2004). Planting date affects the day and night temperature, day light intensity and photoperiods which affect the flower inductions and yield production.

Table (4) Interactive effect of irrigation and planting date on dry flower yield means $(\mathrm{kg} / \mathrm{fed})$ of Hibiscus:

\begin{tabular}{|c|c|c|c|c|}
\hline \multirow{2}{*}{$\begin{array}{c}\text { Planting } \\
\text { dates }\end{array}$} & \multicolumn{4}{|c|}{ Irrigation intervals } \\
\cline { 2 - 5 } & $\begin{array}{c}\text { One week } \\
\text { I1 }\end{array}$ & $\begin{array}{c}\text { Two week } \\
\text { I2 }\end{array}$ & $\begin{array}{c}\text { Three week } \\
\text { I3 }\end{array}$ & Means \\
\hline June & 278.3 & 302.2 & 314.0 & 298.2 \\
\hline July & 267.9 & 281.5 & 281.8 & 277.1 \\
\hline Means & 273.1 & 291.9 & 297.9 & 287.6 \\
\hline
\end{tabular}

Flower dry yield was significantly affected by irrigation levels (Table 4). The maximum flower dry yield was produced under the treatment at June of irrigation to (I3) was 314, as well as the lowest one was produced under the treatment at July of irrigation to I1 was 267.9.

Table (5) Interactive effect of irrigation and planting date on weight of seeds means $(\mathrm{kg} / \mathrm{fed})$ of Hibiscus:

\begin{tabular}{|c|c|c|c|c|}
\hline \multirow{3}{*}{ Planting dates } & \multicolumn{4}{|c|}{ Irrigation intervals } \\
\cline { 2 - 5 } & $\begin{array}{c}\text { One week } \\
\text { I1 }\end{array}$ & $\begin{array}{c}\text { Two week } \\
\text { I2 }\end{array}$ & $\begin{array}{c}\text { Three week } \\
\text { I3 }\end{array}$ & Means \\
\hline June & 694.2 & 766.9 & 793 & 751.4 \\
\hline July & 678.5 & 704 & 704.2 & 695.6 \\
\hline Means & 686.4 & 735.5 & 748.6 & 723.5 \\
\hline
\end{tabular}

Table (5) showed the maximum weight of seeds value was 793 for the treatment $\mathrm{I} 3$ which planting date on June month, while the lowest value was 678.5 for the treatment at July I1. 
Table (6) Interactive effect of irrigation and planting date on No. of branches /plant means of Hibiscus:

\begin{tabular}{|c|c|c|c|c|}
\hline \multirow{3}{*}{ Planting dates } & \multicolumn{4}{|c|}{ Irrigation intervals } \\
\cline { 2 - 5 } & $\begin{array}{c}\text { One week } \\
\text { I1 }\end{array}$ & $\begin{array}{c}\text { Two week } \\
\text { I2 }\end{array}$ & $\begin{array}{c}\text { Three week } \\
\text { I3 }\end{array}$ & Means \\
\hline June & 10.5 & 11.3 & 11.8 & 11.2 \\
\hline July & 5.3 & 5.9 & 5.8 & 5.7 \\
\hline Means & 7.9 & 8.6 & 8.8 & 8.4 \\
\hline
\end{tabular}

Data at table (6) showed the values maximum for No. of branches /plant which planting date on June for the treatment I3 was 11.8 and the lowest value was 5.3 for the treatment at July I1.

Table (7) Interactive effect of irrigation and planting date on plant height (cm) means of Hibiscus:

\begin{tabular}{|c|c|c|c|c|}
\hline \multirow{3}{*}{ Planting dates } & \multicolumn{4}{|c|}{ Irrigation intervals } \\
\cline { 2 - 5 } & $\begin{array}{c}\text { One week } \\
\text { I1 }\end{array}$ & $\begin{array}{c}\text { Two week } \\
\text { I2 }\end{array}$ & $\begin{array}{c}\text { Three week } \\
\text { I3 }\end{array}$ & \multirow{2}{*}{ Means } \\
\hline June & 177.5 & 165.9 & 162.5 & 168.6 \\
\hline July & 162.7 & 149.8 & 146.5 & 153 \\
\hline Means & 170.1 & 157.9 & 154.5 & 160.8 \\
\hline
\end{tabular}

Result at table (7) showed the highest values for the plant height $177.5 \mathrm{~cm}$ with planting date on June for the treatment $I_{1}$, while the lowest value was $146.5 \mathrm{~cm}$ for the treatment $\mathrm{I}_{3}$ with planting date on July. This conforms to the general results for most agricultural crops as reported by Vaux and Pruitt (1983) and Stegman et al (1980 -1983).

\section{Effect of plant densities on the characteristics of hibiscus:}

The results showed that agriculture at small distances tends to increase the length of the plant and therefore tends to produce more fibers. The most appropriate cultivation was at a distance of $40 \mathrm{~cm}$, which obtained the highest productivity of flowers and seeds. This result conforms with Lazim(1973) and by El Naim and Jabereldar (2010) and El Naim et al. (2010a) who stated that an increase in planting population markedly would increase plant height. Difference in plant height was reported by EI Naim and Ahmed, (2010b)

Water use efficiency (W.U.E): 
Table (8): Average values of water use efficiency WUE.

\begin{tabular}{|c|c|c|c|c|c|}
\hline & atm & & Yield kg/Fed & Water & W U E \\
\hline $\mathrm{T} 1$ & D1 & I1 & 274.8 & 4000 & 0.07 \\
\hline & & $\mathrm{I} 2$ & 281.5 & 2000 & 0.14 \\
\hline & & I3 & 290.3 & 1000 & 0.29 \\
\hline & D2 & I1 & 283 & 4000 & 0.07 \\
\hline & & I2 & 329.8 & 2000 & 0.17 \\
\hline & & I3 & 337.8 & 1000 & 0.34 \\
\hline & D3 & I1 & 277.2 & 4000 & 0.07 \\
\hline & & $\mathrm{I} 2$ & 296.2 & 2000 & 0.15 \\
\hline & & I3 & 314 & 1000 & 0.31 \\
\hline $\mathrm{T} 2$ & D1 & I1 & 254.8 & 4000 & 0.06 \\
\hline & & $\mathrm{I} 2$ & 273.4 & 2000 & 0.14 \\
\hline & & $\mathrm{I} 3$ & 273.8 & 1000 & 0.27 \\
\hline & D2 & I1 & 274.2 & 4000 & 0.07 \\
\hline & & $\mathrm{I} 2$ & 287.7 & 2000 & 0.14 \\
\hline & & I3 & 291 & 1000 & 0.29 \\
\hline & D3 & I1 & 274.8 & 4000 & 0.07 \\
\hline & & $\mathrm{I} 2$ & 283.3 & 2000 & 0.14 \\
\hline & & I3 & 280.5 & 1000 & 0.28 \\
\hline
\end{tabular}

The highest water use efficiency was $0.34 \mathrm{~kg} / \mathrm{m}^{3}$ gained from the treatment $\left(\mathrm{T}_{1} \mathrm{D}_{2} \mathrm{I}_{3}\right)$ while the lowest WUE was $0.06 \mathrm{~kg} / \mathrm{m}^{3}$ for T2D1I1. It is logically known that the WUE increases when the amount of applied water decreases, but the crop yield may be decreased. Inspecting all the efficiency results of irrigation with the crop yields, it was found that WUE of $0.34 \mathrm{~kg} / \mathrm{m}^{3}$ corresponded to the yield $337.8 \mathrm{~kg} / \mathrm{Fed}$.

\section{CONCLUSION}

Hibiscus plant was selected to study the effects of planting date, density, and irrigation on the results of the experiment. It is recommended that planting rosella plant at first June, and at distances of $40 \mathrm{~cm}$ between the plants and at intervals of irrigation diverged, was the most suitable to produce the highest growth and yield of plant.

In case of hibiscus cultivation to obtain flowers, irrigation should be extended irrigation to two or three weeks and in quantities of water not exceeding $2000 \mathrm{~m}^{3} /$ fed at distances not less than $40 \mathrm{~cm}$ between plants. In case of hibiscus cultivation to obtain fiber, the irrigation should be approximately at one week intervals and in quantities of water not less than $2000 \mathrm{~m}^{3} /$ fed and at distances not exceeding $25 \mathrm{~cm}$ between plants . 


\section{REFERENCES}

Ado. G.,Indabawa, and Sani K.D.(2015): Effect of Planting Date and Seed Density on the Growth and Yield of Roselle Hibiscus. International Conference on Chemical, Environmental and Biological Sciences (CEBS-2015) March 18-19, 2015 Dubai (UAE)

Babatunde, F.E. and B. Zachariah, 2001. Effect of spacing and weeding regimes on the Productivity of Roselle (Hibiscus sabdariffa. L). Advances in Horticultural Science. 14: 147-151.

Babatunde, F.E., 2003. Intercrop productivity of roselle in Nigeria. Afr. Crop Sci. J., 11: 1-6.

Babatunde, F.E., and A.L.E., Mofoke(2006): Performance of Roselle (Hibiscus sabdariffa L) as Influenced by Irrigation Schedules. in Pakistan Journal of Nutrition 5 (4): 363-367, 2006

Barzgaran $T$ (2010). Effects of irrigation and planting date on agroronomic traits and yield of roselle. M.Sc. Thesis, Department of Agriculture, Islamic Azad University, Birjand Branch, Birjand, Iran, p. 111.

Black, C.A., D.D., Easm L. E.,inager, J. I.White, and F. E.Clark, (1965). Methods of soil Analysis .Part 1l.Agron.ASA and SSSA,Madison,Wl.

Board ;J.E. Kamal, M.and Harville, B.G.(1992) Temporal importance of greater light interception to increase narrow-row soybean. Agro. J. 1992; J84:575-579.

Board J; Kang, MS; Harville,(1999) B,G. Path analysis of the yield formation process for late-planted soybean. Agro. J. 1999; 91: 128135 .

Boquet D.J.( 1990) Plant population density and row spacing effects on soybean at post-optimal planting dates. Agro. J.; 8:,59-64.

Bremner, P. M. and R. W. Radely (1996). Studies in sesame agronomy. 2:

The effect of variety and time of planting on growth, development and yield.J.Agri.Sci.66:253-61.

Cobley, L.S., 1968. An introduction to Botany of Tropical Crops. Longman, London, p: 95-98.

Daneshmand, A; A. Shiranirad; G. Noormohammadi; G. Zareii and J. Daneshian (2008). Effect of water stress and nitrogen on yield, yield 
components and physiological traits of two varieties of canola. J. Sci. and Tech. Agri. and Natu. Res. (abstract in English).15(2): 99112.

El-Boraie, F. M., A. M. Gaber and G. Abdel-Rahman (2009). Optimizing irrigation schedule to maximize water use efficiency of Hibiscus sabdariffa under Shalatien conditions. World J. Agri.Sci.5(4): 50414.

El-Khoby, W. M. (2004). Study the effect of some cultural practices on rice crop. Ph.D. Thesis, Fac Agric Kafr El-sheikh, Tanta Univ.

El Naim A, M. and Jabereldar, A. A., 2010. Effect of Plant density and cultivar on growth and yield of cowpea (Vigna unguiculata L.Walp). Australian Journal of Basic and Applied Sciences, 4(8): 3148-3153

El Naim, A. M., Eldoma, M. A. and Abdalla, A. E. 2010b. Effect of weeding frequencies and plant density on vegetative growth characteristic of groundnut (Arachis hypogaea L.) in North Kordofan of Sudan. International Journal of Applied Biology and Pharmaceutical Technology, 1(3):1188-1193

El Naim, A. M., El day, E. M. and Ahmed, A. A., 2010a. Effect of plant density on the performance of some sesame (Sesamum indicum L) cultivars under Rain -fed. Research Journal of Agriculture and Biological Sciences, 6(4): 498-504

El-Sayed H; Kheir, S.T and Atta, M.B.(1998) Some physico-chemical characteristics and fatty acid composition of roselle (Hibiscus sabdariffa L.) seed oil. Assuit J. Agric. Sci. 29: 103-113.

Fadia El Sherif and Salah Khattab(2012): Effect of seed vernalization temperature, duration and planting date on growth and yield of Hibiscus. International Journal of Agriculture and Forestry 2012, 2(3): 88-91 DOI: 10.5923/j.ijaf.20120203.02

Food and Agriculture Organization of the United Nations (FAO) Hibiscus (2004): Post-Production Management for Improved Market Access. http://www.fao.org/3/a-av006e.pdf.

Ismail, A; Emmy, H.K.I. and Halimatul, S. M. N.(2008) "Roselle (Hibiscus sabdariffa L.) seeds nutritional composition, protein quality and health benefits." 2: 1-16. 
Jackson ML.(1967). Soil Chemical Analysis. Prentice Hall of India, Private Limited; New Delhi, p.115.

Jackson, M.L.(1967). Soil chemical Analysis . Constable Co, Ltd . Lodon Oxoid Manual of Culture Midia, Ingredients and other laboratory. Services 1965. Oxoid limited, London.

Jackson, M.L.(1973) Soil chemical analysis prentice-hall of sndian private limited. New Delhi.

Kantolic, A.G. and Slafer, G.A; (2001). Photoperiod sensitivity after flowering and seed number determination in indeterminate soybean cultivars. Field Crops Res.72, 109-118.

Khater, M.R. and S.K. Ahmed, (1992). Effect of sowing dates and planting distances on vegetative growth yield and active substances on roselle plant. Agric Res. Cent. Hort. Inst. Medicinal and Aromatic Plant Section, Dokki

Lazim, M.E., 1973. Population and cultivar effects on growth and yield of sesame under irrigation. M.Sc. Thesis, Faculty of Agricultural., University of Khartoum

Leung Ay and Foster S. (1996).Encyclopediof common natural Ingredient used in food, Drugs and cosmatics 2 th ed. Johan Wiley and Sons, New yourk.

Michael, A. M. (1978). Irrigation theory and practice. Vikas phb. House PVTLTD New Delhi, Bombay: 360p.

Naeve, S.L; Potter, B.D; Quiring, S.R. Neill, T.A. and Kurle, J.E.(2004). Influence of soybean plant population and row spacing on development and yield across planting dates in Minnesota. Available at - www.soybeans.umn.edu/pdfs/2004asaposter_1_s pacing planting_screen.pdf (verified 11 Dec. 20 07). Un iv. of M in nesot a, Minneapolis.

Naimah et al (2013): Quality and Growth Development of Roselle Grown on Bras Soil in Relation to Regulated Deficit Irrigation. J. Anim. Plant Sci. 23(1):2013

Page, A.L; R.H.Miller and R. Kenney (1982).Methods of soil analysis part 2. Book series No. 9. Am.Soc. of Agron, and soil sci.soc. Am. Madison, Wisconsin, USA. 
Rao, P.U., 1996. Nutrient Composition and Biological Evaluation of Mesta (Hibiscus Sabdariffa. L.) Seeds. Plant Foods for Human Nutrition, 49: 27-34.

Seyyed Gholam and Reza Moosavi 2011): The effect of sowing date and plant density on yield and yield components of roselle. Accepted 30 November, 20111632 J. Med. Plants Res.

Sedecor, G. W., and Cochran (1980). Statistical methods, 7 th ed., Ox ford and J. B. H. Publ com.

Seghatoleslami M., Mousavi S G Barzgaran T. (2013).Effect of irrigation and planting date on morphophysiologicaltratts and yield of roselle (Hbiscus sabdariffa). The Journal of Animal and Plant Sciences; 23: 256-260. ISSN: 1018-7081

Shalaby, A.S. and A.M. Rasin, 1989. Effect of plant spacing on the productivity of Roselle(Hibiscus sabdariffa, L.) grown in newly reclaimed land. National Research Center. Dokki, Cairo, Egypt, Journal of Agronomy and Crop Sciences 162(4): 256260

Shubhra, K., J. Dayal, G. L. Goswami and R. Munjal (2004). Effects of sowing date and plant density on seed and flower yield of pot marigold. Acta Hort.826: 371-376.

Stegman, E.C., J.T. Musick and J.I. Stewart, 1980. Irrigation Water Management. In: "Design and Operation of farm Irrigation Systems". (M. E. Jensen, ed.) ASAE Monograph 3. ASAE. St. Joseph Michigan, 763-801.

Stegman, E.C., (1983). Irrigation Scheduling: Applied Timing Criteria. In : "Advances In Irrigation". Hillel D. (ed). Vol 2. Academic Press, New York, NY, pp: 1-30.

Vaux, H. Jr. and W.O. Pruitt, (1983). Crop Water Production Functions. In: "Advances in Irrigation". Hillel, D. (ed). Vol. 2 .Academic press, New York, NY, pp: 61-93.

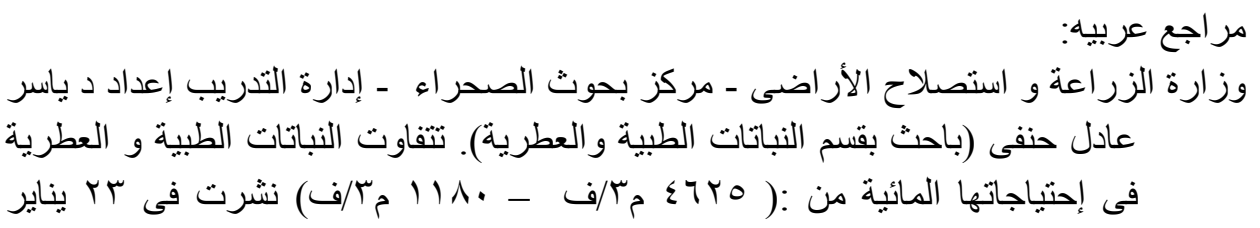




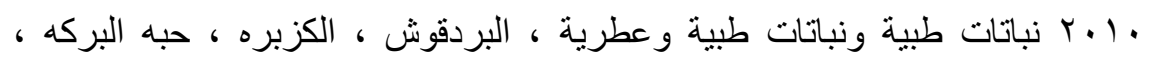

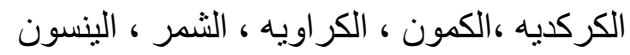
الملخص العربي النيون

تأثير فترات الرى ومواعيد وكثافات الزراعه على انتاجيه الكركديه منصور حامد البخشوان' حامد مبروك القونى'

اجريت تجربة حقلية فى موسم VI I ـ بمحطة ابحاث و اختبار ات الجرارات و الالات الزر اعيةــ

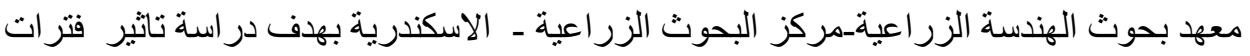

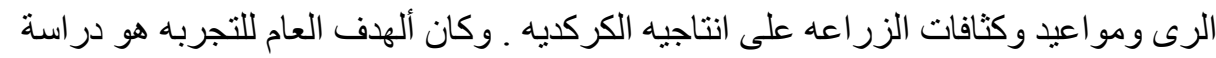

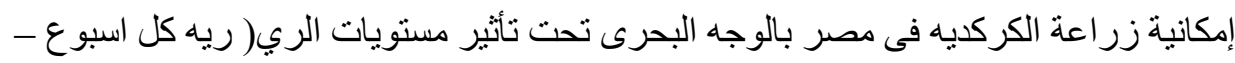

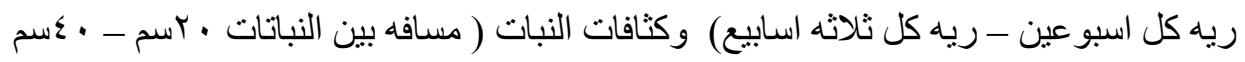

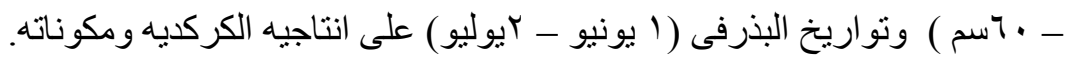

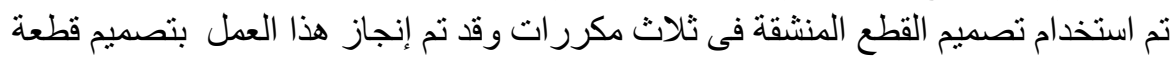

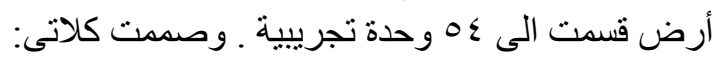

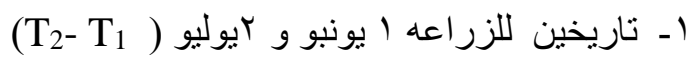

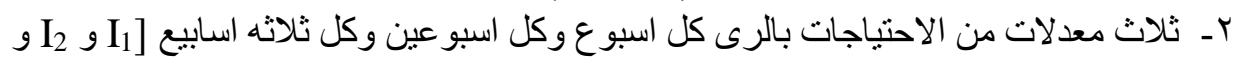
]

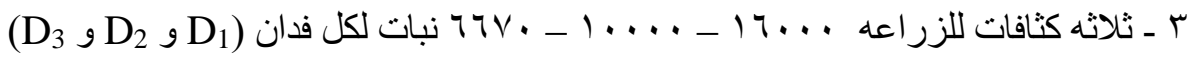

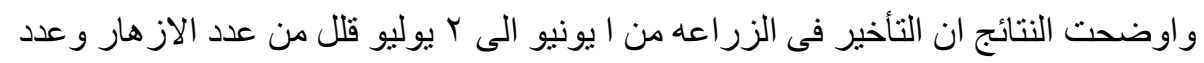

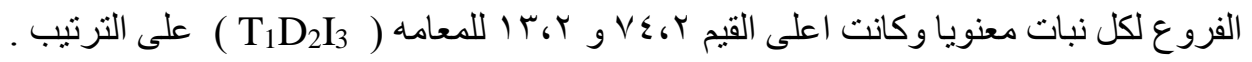

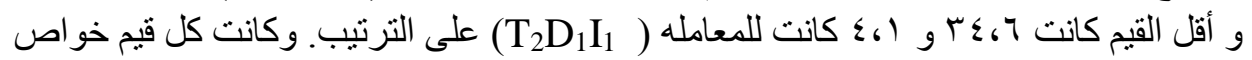

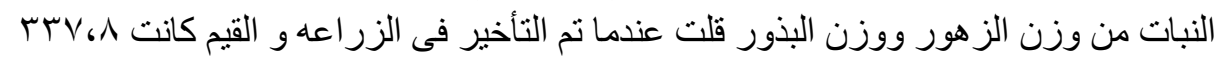

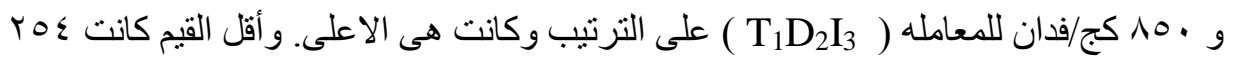

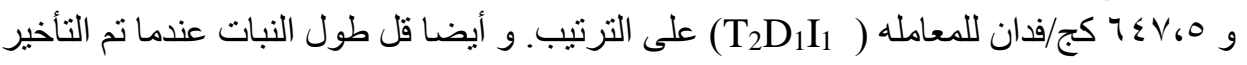

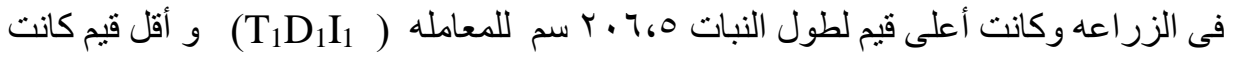
(T)

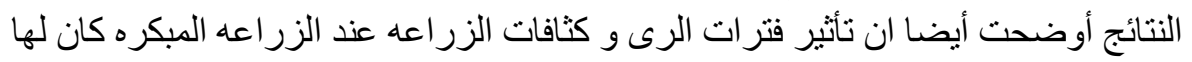

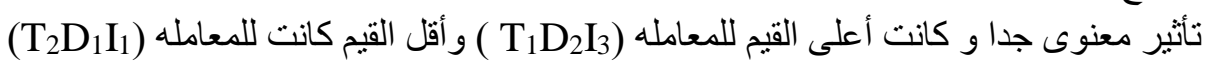

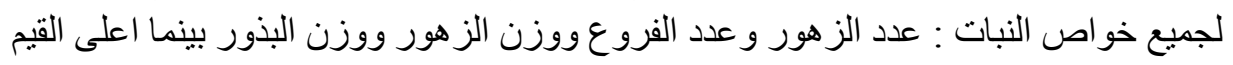

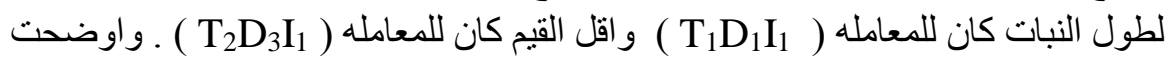
النتائج ايضا ان أعلى قيمه لكفاءه استخدام الرى كانت ع كا، ، للمعامله (

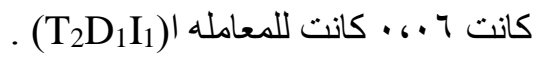

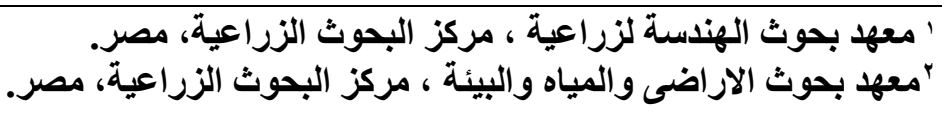

